\title{
Evaluation of the effect of tooth polishing on color stability after in-office bleaching treatment
}

\author{
Avaliação do efeito do polimento dental na estabilidade de cor após \\ tratamento clareador em consultório \\ Luís Felipe ESPÍNDOLA-CASTRO ${ }^{a *}$ (D), Pamella Robertha Rosselinne Paixão CELERINO ${ }^{a}$, \\ Tácyla Alves do NASCIMENTOa ${ }^{a}$, Gabriela Queiroz de Melo MONTEIROa (i), \\ Tereza Cristina CORREIA ${ }^{\mathrm{a}}$ (1) \\ aUPE - Universidade de Pernambuco, Faculdade de Odontologia, Camaragibe, PE, Brasil
}

How to cite: Espíndola-Castro LF, Celerino PRRP, Nascimento TA, Monteiro GQM, Correia TC. Evaluation of the effect of tooth polishing on color stability after in-office bleaching treatment. Rev Odontol UNESP. 2020;49:e20200023.

https://doi.org/10.1590/1807-2577.02320

\begin{abstract}
Resumo
Introdução: Um dos métodos mais usados para dentes pigmentados é o clareamento dental. Entretanto, alterações subclínicas podem ocorrer na micromorfologia dos dentes durante procedimentos de clareamento, como aumentos na porosidade e rugosidade superficial. Consequentemente, o esmalte dental pode se tornar mais permeável e suscetível a manchas. Objetivo: Avaliar a influência do polimento dentário após o clareamento em consultório na estabilidade da cor. Material e método: Trinta e três molares humanos extraídos foram utilizados. Os dentes foram cortados na direção mesiodistal para obter duas amostras por dente (total de 66). As amostras foram divididas aleatoriamente em seis grupos ( $\mathrm{n}=11)$. Antes e após o tratamento clareador, a luminosidade das amostras e a alteração da luminosidade $(\Delta \mathrm{L})$ foram determinadas com um espectrofotômetro digital (Easy Shade). As amostras foram clareadas com peróxido de hidrogênio 35\% (três sessões com intervalos de 7 dias). Três grupos foram submetidos a polimento com discos de feltro e pasta de polimento após cada sessão. Para simular as condições orais durante o consumo de bebidas pigmentadas, as amostras foram submetidas a ciclos alternados de imersão em soluções (café, vinho tinto e Coca Cola). Resultado: 0 polimento resultou em um aumento da luminosidade média de 4,49 no grupo vinho tinto, 2,73 no grupo café e 4,08 no grupo cola. A diferença foi significativa no grupo vinho tinto ( $\mathrm{p}<0,022)$, mas não no grupo café ou cola. Conclusão: 0 polimento após clareamento em consultório usando discos de feltro e pasta polidora pode reduzir o grau de impregnação em pacientes com dieta rica em vinho tinto.
\end{abstract}

Descritores: Polimento dentário; estética; clareamento dental.

\begin{abstract}
Introduction: One of the most commonly used corrective methods for staining teeth is tooth bleaching. However, subclinical alterations may occur in the micromorphology of dental tissues during the bleaching procedure, such as increases in porosity and surface roughness. Consequently, dental enamel may become more permeable and susceptible to staining. Objective: To evaluate the influence of tooth polishing after in-office bleaching treatment on color stability. Material and method: Thirty-three extracted human molars were used. The teeth were cut in the mesiodistal direction to obtain two samples per tooth (total of 66). The samples were randomly divided into six groups $(n=11)$. Before and after the bleaching treatment, the lightness of the samples and change in lightness $(\Delta \mathrm{L})$ were determined with a digital spectrophotometer (Easy Shade). The samples were bleached with 35\% hydrogen peroxide (three sessions weekly). Three groups were submitted to polishing with felt discs and polishing paste after each session. To simulate the oral conditions during the consumption of colored beverages, the samples were submitted to alternating cycles of immersion in staining solutions (coffee, red wine, and Coca Cola). Result: Polishing resulted in an increase of mean lightness of 4.49 in the red wine group, 2.73 in the coffee group, and 4.08 in
\end{abstract}


the cola group. The difference was significant in the red wine group $(\mathrm{p}<0.022)$, but not in the coffee or cola group. Conclusion: Polishing after in-office bleaching using felt discs and polishing paste can reduce the degree of pigment impregnation in patient with red wine rich diet.

Descriptors: Dental polishing; esthetics; tooth bleaching.

\section{INTRODUCTION}

The desire for a harmonious smile appears to be guiding dentistry today. Stain-free, white, well-contoured and properly aligned teeth set the standard for beauty, health, social status, and success $^{1}$. One of the most commonly used corrective methods for staining teeth is tooth bleaching ${ }^{2}$. However, subclinical alterations may occur in the micromorphology of dental tissues during the bleaching procedure, such as increases in porosity and surface roughness 3 . Consequently, dental enamel may become more permeable and susceptible to staining4.

The main bleaching agents used are hydrogen peroxide and carbamide peroxide ${ }^{5}$. Peroxides are compounds with a low molecular weight, which permits their penetration through the porosities of dental tissues ${ }^{3}$. Bleaching agents promote the oxidation of macromolecules in dentin stains and their subsequent breakage into smaller structures and diffusion towards the surface, causing bleaching of the tooth ${ }^{6}$.

An increase in the number of pores on the enamel surface is observed after bleaching treatment, which is accompanied by morphological modifications that are caused mainly by the temporal loss of calcium and phosphorus ${ }^{7}$. Changes in the protein layer of the enamel surface may also occur, a fact that renders this structure even more permeable to the penetration of fluids and consequently more susceptible to staining ${ }^{8}$. Within this context, instructions of not consuming chromogenic foods have been discussed in the literature in an attempt to evaluate their influence on the degree of tooth staining during and/or immediately after treatment $t^{9,10}$.

One possibility to reduce the problems caused by the use of peroxides in tooth bleaching techniques is to perform post-bleaching polishing ${ }^{11}$. Tooth staining after bleaching treatment are closely related to microstructural changes of the enamel surface ${ }^{7}$. Some studies report that the consumption of colored foods immediately after bleaching procedures can increase the staining of teeth because of the greater porosity and permeability of the tooth surface to the penetration of fluids ${ }^{9,10}$. However, few studies have investigated the use of polishing as tool to reduce the risk of discoloration post tooth bleaching. Therefore, the objective of the present study was to evaluate the influence of post-bleaching tooth polishing on color stability. The null hypotheses are: 1) that no significant color differences exist between teeth immersed in different pigmented substances, and 2) that tooth polishing does not significantly affect color changes after bleaching.

\section{MATERIAL AND METHOD}

\section{Study Design}

This in vitro laboratory study was submitted and approved by the Ethics Committee on Research Involving Humans of the University of Pernambuco (Approval No. 2.504.102).

\section{Sample Preparation}

The sample size was determined based on previous similar studies ${ }^{12}$. Thirty-three human molars with healthy enamel extracted due to therapeutic reasons, which were previously stored in distilled water and frozen, were used. The teeth were cut longitudinally in the mesiodistal 
direction with a diamond disc in order to obtained two fragments of each tooth (total of 66). The roots were removed at approximately $4 \mathrm{~mm}$ from the cementoenamel junction, leaving only the coronary portion of each fragment. Before and after cuts, the teeth/samples were examined with a stereoscopic magnifying glass at 40x magnification to verify their integrity. Teeth/samples with enamel defects, cracks and/or fractures were excluded from the study. The samples were fixed in PVC cylinders with acrylic resin, with the enamel surface facing upward. To facilitate sample handling, seal dentin and prevent dentin staining.

\section{Sample Allocation}

The teeth were divided into six groups $(\mathrm{n}=11)$ by simple randomization. The samples were treated by only one operator and assessed by a blinded evaluator (Table 1).

Table 1. Division of the groups

\begin{tabular}{|c|c|}
\hline Group & Treatment \\
\hline Coffee without polishing & $\begin{array}{l}\text { Bleaching with 35\% hydrogen peroxide WITHOUT polishing after bleaching, } \\
\text { immersed in black coffee. }\end{array}$ \\
\hline Coffee with polishing & $\begin{array}{l}\text { Bleaching with } 35 \% \text { hydrogen peroxide WITH polishing after bleaching, immersed } \\
\text { in black coffee. }\end{array}$ \\
\hline Red wine without polishing & $\begin{array}{l}\text { Bleaching with 35\% hydrogen peroxide WITHOUT polishing after bleaching, } \\
\text { immersed in red wine. }\end{array}$ \\
\hline Red wine with polishing & $\begin{array}{l}\text { Bleaching with } 35 \% \text { hydrogen peroxide WITH polishing after bleaching, immersed } \\
\text { in red wine. }\end{array}$ \\
\hline Soft drink without polishing & $\begin{array}{l}\text { Bleaching with 35\% hydrogen peroxide WITHOUT polishing after bleaching, } \\
\text { immersed in soft drink. }\end{array}$ \\
\hline Soft drink with polishing & $\begin{array}{c}\text { Bleaching with } 35 \% \text { hydrogen peroxide WITH polishing after bleaching, immersed } \\
\text { in soft drink. }\end{array}$ \\
\hline
\end{tabular}

Table 2 lists the materials used in the bleaching, polishing and staining procedures.

Table 2. Materials used

\begin{tabular}{ccc}
\hline Product & Commercial name & Batch \\
\hline 35\% Hydrogen peroxide & Whiteness HP (FGM, Santa Catarina, Brazil) & 210618 \\
Felt discs & Diamond Flex (FGM, Santa Catarina, Brazil) & 011117 \\
Polishing paste & Diamond Excel (FGM, Santa Catarina, Brazil) & 012114 \\
& Soluble Nescafe. Proportion of 0.51 g/100 ml & 91011210 \\
Black coffee & (Nestle Brasil, São Paulo, Brazil) & $111913014 \mathrm{~L} 1$ \\
Red wine & Quinta do Morgado (Fante, Rio Grande do Sul, Brazil). & 12141 P300719 \\
Soft drink & Coca Cola (Coca-Cola, Rio de Janeiro, Brazil) \\
\hline
\end{tabular}

\section{Color Measurement}

The difference in the color of the samples before and after the bleaching treatment is expressed as the change in lightness, which is the optical property of teeth along the black-white axis in the CIELAB system. The following formula was applied to evaluate the presence of tooth bleaching or staining: $\Delta \mathrm{L}=\mathrm{L}^{*}{ }_{1}-\mathrm{L}_{0}{ }_{0}$ (reading after bleaching minus reading before bleaching).

Objective color measurement was performed using the VITA Easy Shade digital spectrophotometer (Wilcos, Rio de Janeiro, Brazil) according to manufacturer's instructions. Two measurements were obtained per tooth at each time point and the mean was used for analysis. To standardize the position for analysis before and after bleaching, a matrix was vacuum 
fabricated with a 1-mm acetate plate and a hole corresponding to the tip diameter of the digital spectrophotometer (Easy Shade) was made on the buccal side.

\section{Bleaching Procedures}

Bleaching was performed with the same agent (Whiteness HP, FGM, Santa Catarina, Brazil) in all groups. The gel was applied to the surface of the samples according to manufacturer's recommendations (three 15-minute applications per session). Bleaching was performed in three sessions at intervals of 7 days between sessions. During the intervals, the samples were stored in artificial saliva $(0.625 \%$ potassium chloride, $0.865 \%$ sodium chloride, $0.0558 \%$ magnesium chloride, $0.1662 \%$ calcium chloride, and $100 \mathrm{ml}$ distilled water). The saliva was changed weekly.

\section{Polishing}

In the coffee ${ }^{13}$, red wine and cola groups submitted to polishing, the samples were polished with felt discs (Diamond Flex, FGM, Santa Catarina, Brazil) and polishing paste (Diamond Excel, FGM, Santa Catarina, Brazil) after each bleaching session. The felt discs received a small amount $(0.1 \mathrm{~g})$ of polishing paste and were pressed against the sample surface for $20 \mathrm{~s}$ under low rotation.

\section{Immersion in Pigmented Substances}

To simulate the oral condition during the consumption of colored beverages, the specimens were submitted to alternating cycles of immersion in colored beverages and artificial saliva. A complete immersion cycle consisted of the following steps: 1) 5 minutes in $3 \mathrm{~mL}$ of the potential staining solution (coffee, red wine, and cola-based soft drink); 2) rinsing with distilled water $(3 \mathrm{~mL})$, and 3) storage in artificial saliva for 4 hours. The cycle was repeated four times per day for 21 days.

Each sample was immersed in the solutions in individual glass tubes under gentle shaking at room temperature. The solution was changed at each cycle. During the intervals, the specimens were stored in artificial saliva.

\section{Statistical Analysis}

The data were entered into a Microsoft Excel spreadsheet, which was exported to the SPSS 18 software for analysis. To evaluate the degree of bleaching of the materials after the experiment, the mean change in lightness before and after treatment was calculated. The Shapiro-Wilk test was used to verify the normality of the data. Since the changes in lightness showed a normal distribution, the Student t-test was applied for comparison between the groups with and without polishing. The tested products were compared by ANOVA in the groups with or without polishing. All conclusions were drawn considering a level of significance of $5 \%$.

\section{RESULT}

Table 3 shows the mean lightness change of the samples according to the tested product and use of polishing. In the groups submitted to polishing, a greater reduction in lightness (staining) was observed in the soft drink group (mean $=-12.38$ ), followed by the red wine ( $m e a n=-5.82$ ) and coffee group (mean $=-0.54$ ). In the groups without polishing, the use of soft drink resulted in an even greater reduction of mean lightness than in the group submitted to polishing 
( mean $=-16.46)$, followed by red wine (mean $=-10.31)$ and coffee (mean $=-3.27$ ). ANOVA showed a significant difference between the groups submitted or not to polishing $(\mathrm{p}<0.05$ for both), indicating a relevant difference in the level of staining between the products evaluated. Comparison of the use or not of polishing revealed an increase in the lightness change of the samples for all tested products but the difference was only significant for the red wine group $(p=0.022)$, in which a higher value was observed for the group without polishing (mean $=-10.31$ ) compared to the group with polishing (mean $=-5.82$ ).

Table 3. Analysis of variance of changes in lightness of the samples according to tested product and use of polishing

\begin{tabular}{cccc}
\hline \multirow{2}{*}{ Tested product } & \multicolumn{2}{c}{ Group } & \multirow{2}{*}{ p-value $^{\mathbf{1}}$} \\
\cline { 2 - 3 } & With polishing & Without polishing & \\
\hline Red wine & $-5.82(3.82)$ & $-10.31(4.63)$ & 0.022 \\
Coffee & $-0.54(4.02)$ & $-3.27(3.19)$ & 0.093 \\
Soft drink & $-12.38(6.87)$ & $-16.46(3.44)$ & 0.099 \\
p-value ${ }^{2}$ & $<0.001$ & $<0.001$ & - \\
\hline
\end{tabular}

${ }^{1}$ Student $t$-test for paired samples. ${ }^{2}$ ANOVA.

\section{DISCUSSION}

The first hypothesis that no difference exists in the staining potential of the pigmented substances was rejected $(\mathrm{p}<0.001)$. Coffee was found to cause less staining than the other colored solutions. The second hypothesis that post-bleaching polishing exerts no effect on the esthetic outcome was also rejected, since a statistically significant difference was observed in the red wine group ( $\mathrm{p}<0.022)$.

The samples were immersed in highly pigmented substances (red wine, cola-based soft drink, and coffee). In the intervals between treatments, the samples were stored in artificial saliva containing calcium and phosphate ions to simulate the remineralization of bleached teeth ${ }^{14}$. According to Monteiro et al. ${ }^{15}$, saliva is an essential factor in the prevention of tooth staining. The artificial saliva can reverse the minerals loss of enamel and reduce the enamel porosity caused by bleaching treatment ${ }^{4}$. It is important to mention that although bleaching agents can induce alterations on the dental surface ${ }^{16}$, immersion in artificial saliva after bleaching showed a significant effect on enamel roughness reduction and the immersion for $2 \mathrm{~h}$ in is effective in preventing bleached enamel staining 4 .

A recent study demonstrated that surface treatments ( $2 \%$ neutral sodium fluoride, CPP-ACPF, PVP-containing rinse, and polishing with feltrum disks impregnated with aluminum oxide) were similar to artificial saliva and did not affect bleached enamel color maintenance ${ }^{17}$. These findings partially corroborate with the present study. In the Coffee and Coca Cola groups, polishing and only immersion in saliva were equivalent in preventing pigmentation. However, in the red wine group, polishing after tooth bleaching was statistically superior to the group just immersed in artificial saliva.

A digital spectrophotometer was used for color measurement since the perception of color by visual analysis is a subjective interpretation and varies among different observers. This variability is due to factors such as the object examined, lighting, metamerism, and fatigue, age and emotional state of the observers ${ }^{18,19}$. According to Liberato et al. ${ }^{20}$, the use of equipment for color measurement is a more accurate, reproducible and reliable method than human visual assessment. Furthermore, the Easy Shade ${ }^{\circledR}$ spectrophotometer has been used to improve the color reproduction of ceramic restorations in clinical practice and in the dental laboratory ${ }^{21}$. 
The present study demonstrated the influence of pigmented substances on the color of bleached teeth. To Nogueira et al. ${ }^{22}$, the consumption of pigment drinks during the bleaching treatment can influence the speed of treatment. This surface is likely to be more susceptible to staining ${ }^{15}$. Côrtes et al. ${ }^{4}$ also observed the staining of teeth during and after bleaching treatment when teeth are immersed in coffe and red wine. During the treatment, the remineralization of the enamel with artificial saliva were effective in preventing enamel staining ${ }^{4}$. However after the bleaching procedures, both stain therapies (coffee and red wine) caused enamel color changes. These drinks also have the ability to staining composite resins ${ }^{18}$.

Carlos et al. ${ }^{9}$ evaluated color changes after bleaching and immersion of bovine teeth in pigmented substances (coffee and Coca Cola) and observed less discoloration in the groups immersed in coffee compared to those treated with Coca Cola. These findings agree with the present study in which the level of tooth discoloration (lower $\Delta \mathrm{L}$ ) was lower for samples immersed in coffee ${ }^{9}$. This result may be related to the fact that acid beverages (soft drinks) have a greater demineralization potential and cause alterations in enamel morphology9,15. On the other hand, Liporoni et al. ${ }^{8}$, who evaluated the post-bleaching staining of teeth immersed in coffee and red wine 30 or 150 minutes after the bleaching procedure, found no difference between waiting times for either beverage. However, the bleached enamel was susceptible to staining with red wine at both time points, while it did not influence the bleaching process. The presence of ethanol in alcoholic beverages such as red wine may facilitate the binding of pigments to enamel ${ }^{23}$.

The coffee-immersed group in which polishing was performed had a $\Delta \mathrm{L}$ of 0.54 . The group immersed in coffee without polishing had a $\Delta \mathrm{L}$ of 3.27. Color variation values greater than or equal to 3.3 show unacceptable clinical color changes ${ }^{13}$. These results show that polishing after tooth bleaching, despite favoring minor changes in luminosity, is not superior to the group just immersed in saliva.

Hwang et al. ${ }^{24}$ also observed that acidic and alcoholic beverages in the composition may accentuate the pigmentation of composite resin restorations. The authors state that the color change was enhanced by the presence of ethanol, increasing the pigment penetration in the resin. These results agree with the present study. The groups immersed in coca-cola and red wine showed higher values of decay of luminosity (Table 3).

Regarding the influence of post-bleaching polishing on color stability, the degree of tooth staining was lower (lower $\Delta \mathrm{L}$ ) in the groups submitted to this procedure. However, postbleaching polishing only exerted a significant effect in the red wine group $(p<0.022)$. These findings disagree with those reported by Monteiro et al. ${ }^{15}$ who found no statistically significant differences between teeth immersed in red wine for 15 minutes treated only with artificial saliva and those submitted to post-bleaching polishing.

In addition to improving the esthetic outcome, the smooth surface obtained by polishing prevents the formation of a pigmented biofilm and the retention of plaque because of the absence of microrugosities ${ }^{25}$. According to Freitas et al. ${ }^{26}$, polishing at the end of each bleaching session is aimed at reducing structural alterations caused by the bleaching agents, particularly minimizing surface roughness and consequently increasing surface gloss. In a study evaluating the surface roughness index, color and gloss of enamel of human central incisors bleached and polished using three different bleaching protocols, the authors obtained positive results in terms of reduced surface roughness and increased gloss when the teeth were polished.

One of the limitations of the present study is the difficulty in reproducing natural clinical conditions. This limitation is present in all in vitro studies. Randomized clinical trials and systematic reviews could provide further scientific evidence. However, clinical trials evaluating the influence of polishing after tooth whitening would be difficult to control variables and could subject the research participants to the risk of dental staining. 


\section{CONCLUSION}

Polishing after in-office bleaching using felt discs and polishing paste reduced the degree of pigment impregnation in the groups immersed in red wine. In the Coffee and Coca-cola groups, polishing after tooth bleaching was not efficient in reducing pigmentation. Analyzing the patient's diet can be an important factor in choosing a therapeutic decision.

\section{ACKNOWLEDGEMENTS}

This work was carried out with the support of the Higher Education Personnel Improvement Coordination - Brazil (CAPES) - Financing Code 001

\section{REFERENCES}

1. Armalaite J, Jarutiene M, Vasiliauskas A, Sidlauskas A, Svalkauskiene V, Sidlauskas M, et al. Smile aesthetics as perceived by dental students: a cross-sectional study. BMC Oral Health. 2018 Dec;18(1):225. http://dx.doi.org/10.1186/s12903-018-0673-5. PMid:30577772.

2. Faus-Matoses V, Palau-Martínez I, Amengual-Lorenzo J, Faus-Matoses I, Faus-Llácer VJ. Bleaching in vital teeth: combined treatment vs in-office treatment. J Clin Exp Dent. 2019 Aug;11(8):e754-8. http://dx.doi.org/10.4317/jced.56079. PMid:31598205.

3. Acuña ED, Parreiras SO, Favoreto MW, Cruz GP, Gomes A, Borges CPF, et al. In-office bleaching with a commercial $40 \%$ hydrogen peroxide gel modified to have different pHs: color change, surface morphology, and penetration of hydrogen peroxide into the pulp chamber. J Esthet Restor Dent. 2019 Feb PMid:30790402.

4. Côrtes G, Pini NP, Lima DANL, Liporoni PCS, Munin E, Ambrosano GMB, et al. Influence of coffee and red wine on tooth color during and after bleaching. Acta Odontol Scand. 2013 Nov;71(6):1475-80. http://dx.doi.org/10.3109/00016357.2013.771404. PMid:23421870.

5. Llena C, Forner L, Esteve I. Effect of hydrogen and carbamide peroxide in bleaching, enamel morphology, and mineral composition: in vitro study. J Contemp Dent Pract. 2017 Jul;18(7):576-82. http://dx.doi.org/10.5005/jp-journals-10024-2087. PMid:28713111.

6. Pecho OE, Martos J, Pinto KVA, Pinto KVA, Baldissera RA. Effect of hydrogen peroxide on color and whiteness of resin-based composites. J Esthet Restor Dent. 2019 Mar;31(2):132-9. http://dx.doi.org/10.1111/jerd.12443. PMid:30499175.

7. Melo CFM, Manfroi FB, Spohr AM. Microhardness and roughness of enamel bleached with $10 \%$ carbamide peroxide and brushed with different toothpastes: an in situ study. J Int Oral Health. 2014 Jul;6(4):18-24. PMid:25214727.

8. Liporoni PCS, Souto CMC, Pazinatto RB, Cesar ICR, de Rego MA, Mathias P, et al. Enamel susceptibility to coffee and red wine staining at different intervals elapsed from bleaching: a photoreflectance spectrophotometry analysis. Photomed Laser Surg. 2010 Oct;28(Suppl 2):S105-9. http://dx.doi.org/10.1089/pho.2009.2627. PMid:20863240.

9. Carlos NR, Pinto AVD, Amaral FLB, França FMG, Turssi CP, Basting RT. Influence of staining solutions on color change and enamel surface properties during at-home and in-office dental bleaching: an in situ study. Oper Dent. 2019 Nov-Dec;44(6):595-608. http://dx.doi.org/10.2341/18-236-C. PMid:31034349.

10. Crastechini E, Borges AB, Torres CRG. Effect of remineralizing gels on microhardness, color and wear susceptibility of bleached enamel. Oper Dent. 2019 Jan-Feb;44(1):76-87.

http://dx.doi.org/10.2341/17-150-L. PMid:29953340. 
11. Russo DS, Viano M, Bambi C, Nieri M, Giachetti L. Color stability of bleached teeth over time: an in vitro study. Eur J Esthet Dent. 2010;5(3):300-10. PMid:20820459.

12. Al-Angari SS, Lippert F, Platt JA, Eckert GJ, González-Cabezas C, Li Y, et al. Bleaching of simulated stained-remineralized caries lesions in vitro. Clin Oral Investig. 2019 Apr;23(4):1785-92. http://dx.doi.org/10.1007/s00784-018-2590-z. PMid:30182319.

13. Espíndola-Castro LF, Brito OFF, Araújo LGA, Santos ILA, Monteiro GQM. In vitro evaluation of physical and mechanical properties of light-curing resin cement: a comparative study. Eur J Dent. 2020 Feb;14(1):152-6. http://dx.doi.org/10.1055/s-0040-1705075. PMid:32168541.

14. Batista GR, Torres CRG, Sener B, Attin T, Wiegand A. Artificial saliva formulations versus human saliva pretreatment in dental erosion experiments. Caries Res. 2016;50(1):78-86. http://dx.doi.org/10.1159/000443188. PMid:26870948.

15. Monteiro D, Moreira A, Cornacchia T, Magalhães C. Evaluation of the effect of different enamel surface treatments and waiting times on the staining prevention after bleaching. J Clin Exp Dent. 2017 May;9(5):e677-81. http://dx.doi.org/10.4317/jced.53712. PMid:28512546.

16. Pinto CF, Oliveira R, Cavalli V, Giannini M. Peroxide bleaching agent effects on enamel surface microhardness, roughness and morphology. Braz Oral Res. 2004 Oct-Dec;18(4):306-11. http://dx.doi.org/10.1590/S1806-83242004000400006. PMid:16089261.

17. Monteiro DDH, Valentim PT, Elias DC, Moreira AN, Cornacchia TPM, Magalhães CS. Effect of surface treatments on staining and roughness of bleached enamel. Indian J Dent Res. 2019 May-Jun;30(3):3938. http://dx.doi.org/10.4103/ijdr.IJDR_233_16. PMid:31397414.

18. Silva VA, Silva SA, Pecho OE, Bacchi A. Influence of composite type and light irradiance on color stability after immersion in different beverages. J Esthet Restor Dent. 2018 Sep;30(5):390-6. http://dx.doi.org/10.1111/jerd.12383. PMid:29920918.

19. Giudice RL, Pantaleo G, Lizio A, Romeo U, Castiello G, Spagnuolo G, et al. Clinical and spectrophotometric evaluation of LED and laser activated teeth bleaching. Open Dent J. 2016 May;10(1):242-50. http://dx.doi.org/10.2174/1874210601610010242. PMid:27386010.

20. Liberato WF, Barreto IC, Costa PP, Almeida CC, Pimentel W, Tiossi R. A comparison between visual, intraoral scanner, and spectrophotometer shade matching: a clinical study. J Prosthet Dent. 2019 Feb;121(2):271-5. http://dx.doi.org/10.1016/j.prosdent.2018.05.004. PMid:30722987.

21. Kalantari MH, Ghoraishian SA, Mohaghegh M. Evaluation of accuracy of shade selection using two spectrophotometer systems: vita easyshade and degudent shadepilot. Eur J Dent. 2017 AprJun;11(2):196-200. http://dx.doi.org/10.4103/ejd.ejd_195_16. PMid:28729792.

22. Nogueira JSP, Lins-Filho PC, Dias MF, Silva MF, Guimarães RP. Does comsumption of staining drinks compromise the result of tooth whitening? J Clin Exp Dent. 2019 Nov;11(11):e1012-7. http://dx.doi.org/10.4317/jced.56316. PMid:31700575.

23. Ribeiro JS, Peralta SL, Salgado VE, Lund RG. In situ evaluation of color stability and hardness' decrease of resin-based composites. J Esthet Restor Dent. 2017 Sep;29(5):356-61. http://dx.doi.org/10.1111/jerd.12319. PMid:28737281.

24. Hwang S, Chung SH, Lee JT, Kim YT, Kim YJ, Oh S, et al. Influence of acid, ethanol, and anthocyanin pigment on the optical and mechanical properties of a nanohybrid dental composite resin. Materials. 2018 Jul;11(7):1234. http://dx.doi.org/10.3390/ma11071234. PMid:30021991.

25. Go H, Park H, Lee J, Seo H, Lee S. Effect of various polishing burs on surface roughness and bacterial adhesion in pediatric zirconia crowns. Dent Mater J. 2019 Mar;38(2):311-6. http://dx.doi.org/10.4012/dmj.2018-106. PMid:30814454.

26. Freitas ACP, Botta SB, Teixeira FS, Salvadori MCBS, Garone-Netto N. Effects of fluoride or nanohydroxiapatite on roughness and gloss of bleached teeth. Microsc Res Tech. 2011 Dec;74(12):1069-75. http://dx.doi.org/10.1002/jemt.20996. PMid:21563265. 


\section{CONFLICTS OF INTERESTS}

The authors declare no conflicts of interest.

\section{*CORRESPONDING AUTHOR}

Luís Felipe Espíndola-Castro, UPE - Universidade de Pernambuco, Faculdade de Odontologia, Av. General Newton Cavalcanti, 1650, Tabatinga, 54756-220 Camaragibe - PE, Brasil, e-mail: lipe_espindola@hotmail.com

Received: April 15, 2020

Accepted: June 29, 2020 